\title{
Benchmarking of mobile apps on heart failure
}

\author{
Benchmarking de aplicativos móveis sobre insuficiência cardíaca \\ Benchmarking de aplicaciones móviles sobre insuficiencia cardíaca
}

Virna Ribeiro Feitosa Cestari' ORCID: 0000-0002-7955-0894

Raquel Sampaio Florêncio' ORCID: 0000-0003-3119-7187

Thiago Santos Garces' ORCID: 0000-0002-1670-725X

Vera Lucia Mendes de Paula Pessoa' ORCID: 0000-0002-8158-7071

Thereza Maria Magalhães Moreira' ORCID: 0000-0003-1424-0649

'Universidade Estadual do Ceará. Fortaleza, Ceará, Brazil.

How to cite this article:

Cestari VRF, Florêncio RS, Garces TS, Pessoa VLMP, Moreira TMM. Benchmarking of mobile apps on heart failure. Rev Bras Enferm. 2022;75(1):e20201093. https://doi.org/10.1590/0034-7167-2020-1093

Corresponding author: Virna Ribeiro Feitosa Cestari E-mail: virna.ribeiro@hotmail.com

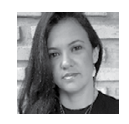

EDITOR IN CHIEF: Antonio José de Almeida Filho ASSOCIATE EDITOR: Alvaro Sousa

Submission: 11-25-2020

Approval: 04-12-2021

\section{ABSTRACT}

Objective: to analyze the mobile apps on heart failure available in the main operating systems and their usability. Methods: benchmarking of mobile applications, systematic research, comprising 38 mobile applications for analysis of general information, functionalities and usability. Usability was assessed using System Usability Scale and Smartphone Usability Questionnaire, followed by the calculation of the agreement index and the exact binomial distribution test, with a significance level of $p>0.05$ and a proportion of 0.90 . Results: mobile applications had English as the predominant language (73.7\%), were directed to patients $(71.1 \%)$ and the predominant theme was disease knowledge (34.2\%). Functionalities ranged from general features to the need for an internet connection. In assessing usability, heart failure was shown to be $92.1 \%-94.7 \%$ and $p<0.05$. Final considerations: the mobile apps on heart failure have varied content and adequate usability. However, there is a need to develop more comprehensive mobile applications.

Descriptors: Heart Failure; Mobile Applications; Telemedicine; Health Promotion; Diffusion of Innovation..

\section{RESUMO}

Objetivo: analisar os aplicativos móveis sobre insuficiência cardíaca disponíveis nos principais sistemas operacionais e sua usabilidade. Métodos: benchmarking de aplicativos móveis, pesquisa sistemática, contemplando 38 aplicativos móveis para análise das informações gerais, funcionalidades e usabilidade. A usabilidade foi avaliada por dois instrumentos: System Usability Scale e Smartphone Usability Questionnaire, seguido do cálculo do índice de concordância e teste exato de distribuição binomial, sendo o nível de significância $p>0,05$ e proporção de 0,90 . Resultados: os aplicativos móveis tiveram o inglês como idioma predominante $(73,7 \%)$ eram direcionados aos pacientes $(71,1 \%)$ e com temática predominante o conhecimento da doença $(34,2 \%)$. As funcionalidades variaram de recursos gerais à necessidade de conexão com a internet. Na avaliação da usabilidade, mostraram-se insuficiência cardíaca interrevisores de $92,1 \%-94,7 \%$ e p>0,05. Considerações finais: os aplicativos móveis sobre insuficiência cardíaca possuem conteúdo variado e usabilidade adequada. Contudo, há necessidade de desenvolvimento de aplicativos móveis mais abrangentes.

Descritores: Insuficiência Cardíaca; Aplicativos Móveis; Telemedicina; Promoção da Saúde; Difusão de Inovações.

\section{RESUMEN}

Objetivo: analizar las aplicaciones móviles sobre insuficiencia cardíaca disponibles en los principales sistemas operativos y su usabilidad. Métodos: benchmarking de aplicaciones móviles, investigación sistemática, contemplando 38 aplicaciones móviles para análisis de información general, funcionalidades y usabilidad. La usabilidad se evaluó mediante dos instrumentos: System Usability Scale y Smartphone Usability Questionnaire, seguido del cálculo del índice de concordancia y la prueba de distribución binomial exacta, con un nivel de significancia de $p>0.05$ y una proporción de 0.90 . Resultados: las aplicaciones móviles tuvieron el inglés como idioma predominante $(73,7 \%)$, fueron dirigidas a pacientes $(71,1 \%$ y con un tema predominante el conocimiento de la enfermedad (34,2\%). Las funcionalidades iban desde características generales hasta la necesidad de una conexión a Internet. En la evaluación de usabilidad, se demostró que la insuficiencia cardíaca era del $92,1 \%-94,7 \%$ y p $>0,05$. Consideraciones finales: las aplicaciones móviles sobre insuficiencia cardíaca tienen un contenido completo y una usabilidad adecuada. Sin embargo, es necesario desarrollar aplicaciones móviles más completas.

Descriptores: Insuficiencia Cardíaca; Aplicaciones Móviles; Telemedicina; Promoción de la Salud; Difusión de Innovaciones. 


\section{INTRODUCTION}

Heart failure (HF) is an emerging global threat, with a current prevalence of 64.34 million cases on the planet $(8.52$ per 1,000 inhabitants), representing 9.91 million years lost due to disability and spending of US\$346.17 billion $^{(1)}$, with a prospect of an increase despite therapeutic advances. These data alert to the prioritization of preventive actions and the imminence of considering new ways of care.

In order to facilitate the process of caring for people with $\mathrm{HF}$, mHealth technologies, such as mobile applications (APP), stand out. In recent years, the number of APPs has increased exponentially in the most varied areas and has contributed to increase productivity and quality of health care, in addition to allowing the use of the most up-to-date clinical knowledge and supporting the clinical decision-making of professionals ${ }^{(2-3)}$. When undertaken in the care of patients with HF, APPs contribute to survival and improved quality of life ${ }^{(4-6)}$.

After creating an APP, it is necessary to evaluate its content and functionality, to ensure the launch of a product suitable for the target audience. The development demands an understanding of functionalities and previous knowledge of APP already built for the theme. In this process, benchmarking is a technique that allows assessment of performance and results of this technology, analyzing, conclusively, whether they are positive or negative ${ }^{(7)}$.

The evaluative concern was observed in studies that reviewed self-care APP for patients with $\mathrm{HF}^{(8-9)}$, which corroborate that the existing ones are incomplete, of low quality, with bugs and unsuitable to the target audience, having little impact in disease management, in addition to excluding professionals and family members/caregivers. Still, they address only self-care, an important element in the complexity of a person with $\mathrm{HF}^{(10)}$, but not the only one.

The need to expand the review of APPs is highlighted, to cover all content and resources produced about HF and to involve all participants in the care process. Thus, it was proposed a systematic survey of all APPs about HF currently available in the virtual stores Play Store and App Store, aimed at patients and their families/caregivers and health professionals. Investigating its functionality and usability is essential to maximize its potential health promoter.

\section{OBJECTIVE}

To analyze the mobile apps on heart failure available in the main operating systems and their usability.

\section{METHODS}

\section{Ethical aspects}

This study did not require prior approval from an Institutional Review Board. Even so, the researchers' ethical commitment is reiterated, as recommended by Resolution 466/12 of the Brazilian National Research Council (Conselho Nacional de Saúde).

\section{Type of study}

This is a benchmarking of mobile applications, a systematic survey that sought to identify all the APPs about HF and their usability in the main operating systems.

\section{Methodological procedures}

In order to systematize the data collection for conducting benchmarking, the steps of the Preferred Reporting Items for Systematic Reviews and Meta-Analyzes (PRISMA) checklist were followed. The steps taken were: 1) establishment of analytical objectives; 2 ) choice of terms; 3 ) enumeration of APP inclusion/ exclusion criteria; 4) definition of information to be extracted; 5) analysis of results; 6 ) presentation of results and discussion.

Initially, the objectives of analysis were established: to identify APP over HF, download, analyze content and functionalities and classify them according to usability. The search was made easier with the use of heart failure terms.

APPs were included in the survey in any language that covered the $\mathrm{HF}$ theme and excluded if 1 ) required payment for installation, 2) needed author release for use (registration number and password), 3) were intended for event monitoring/scientific conference, 4) contained only books or guidelines, 5) acted as general health calculators, unspecific for HF and 6) provided only vital signs.

\section{Data source}

Searches for APPs were carried out in the Play Store and App Store virtual stores of iOS (Apple) and Android (Google) operating systems, respectively.

\section{Data collection and organization}

Two independent reviewers performed the screening of APPs in virtual stores. For this, three devices were used: a Samsung Galaxy S8, compatible with Android; an iPhone XS Max and an iPad Pro, version iPadOS 13.5.1, compatible with iOS.

Four searches were carried out in each virtual store, using each of the previously established terms individually. After the research, the APPs were previously selected via title and short description. This screening served to separate most APPs on cardiac health, in a generalized way. APPs that met the inclusion and exclusion criteria were downloaded and analyzed.

Each reviewer organized the APPs in an information matrix in Microsoft Excel ${ }^{\circ}$, with description of identification (name, developer, author (s) responsible, year of launch, language, country of origin), target audience (patient, family/caregivers and students or health professionals), APP data (description, current version, number of downloads, rating/evaluation), content, features (features) and usability.

Draft of the data extraction tool was modified and revised, as needed, during the data extraction process for each included APP. Additional information and comments were recorded individually for further analysis. 
APPs were tested for two weeks, as some needed control for a minimum period of one week to provide data (graphs) to users. At the end of that period, the researchers felt safe to collect the data and assess its usability.

\section{Data analysis}

The two independent reviewers carried out usability assessment mediated by two instruments. The first was the System Usability Scale (SUS) questionnaire, created by John Brooke, in 1986, and validated in Brazil by Tenório(11). The SUS questionnaire is used to evaluate products, services, hardware, software, websites and applications. It consists of ten questions and, for each one, users can answer on a scale of 1 (I strongly disagree) to 5 (I strongly agree).

For usability calculation, 1 is subtracted from the score for odd answers, and for even answers, the answer is subtracted from 5. To obtain the final average, multiply the value found by 2.5 , which will give the final score (between 0 to 100). The SUS average is 68 points; below this value, the product has usability problems. Software that scores above 85 has excellent acceptance by users ${ }^{(12)}$.

The second questionnaire was version 1.0 of Smartphone Usability questionnaiRE (SURE), built and validated by Wangenheim et al. ${ }^{(11)}$ after an exhaustive systematic literature review and the use of Item Response Theory (IRT) for the construction of its items. This questionnaire has 31 items and measures the usability of a smartphone APP at levels ranging from 30 (all respondents are more likely to disagree partially or totally with the items) to 80 (respondents begin to fully agree that the help/tip given by APP was helpful) $)^{(13)}$.

The variables contained in the information matrix were analyzed and, when necessary, described using absolute and relative frequencies. To calculate the percentage of agreement between reviewers, the Agreement Index was adopted, considering an acceptable agreement rate of $90 \%{ }^{(14)}$. An exact test of binomial distribution was performed, indicated for small samples, with a significance level of $p>0.05$ and a proportion of 0.90 of agreement, to estimate the statistical reliability of HF. Discrepancies in relation to the score were resolved through critical discussion among the reviewers.

\section{RESULTS}

The search resulted in 328 APPs, 250 in the Play Store and 78 in the App Store. After analyzing their titles, description of content and excluding duplicates, 316 were screened. After excluding those not related to the theme, 59 were selected for download and installed for complete evaluation. The APP selection process was described in Figure 1.

At the end, 38 APPs were analyzed. Figure 2 shows the APP logos, named, horizontally, from left to right: MyHeartAPP, CardioCALC, Insuficiencia Cardíaca, WOWME 2000, LifeCourse HF, Medly for Heart Failure, CardioExpert I, Heart Failure Manager, CardioSmart Heart Failure Explorer, Heart Failure-AZ Discussions, 3C-HF Score Calculator, Leben mit Herzinsuffizienz, LifeCurse Companion, Patient Education Atlas of Heart Failure, Rajan's HF (R-hf) Risk Calculator, FAQs Heart Failure, Cardiac Care Plan, Slabe Serce, CV Risk Prognostic Model iCerca, ICFEP, iCAPP, HF Log,
Cardiac Nursing Care Plans, CardioEnf-IC, Heart Failure, Heart Failure Info, Heart Failure Storylines, Clinical Cardiology, HF Path, CardioMed, CardioVisual, CaPriMur, ADHF/NT-preBNP Risk Score Calculator, HF Buddy, TreatHF, MED-HF, and Systolic Heart Failure.

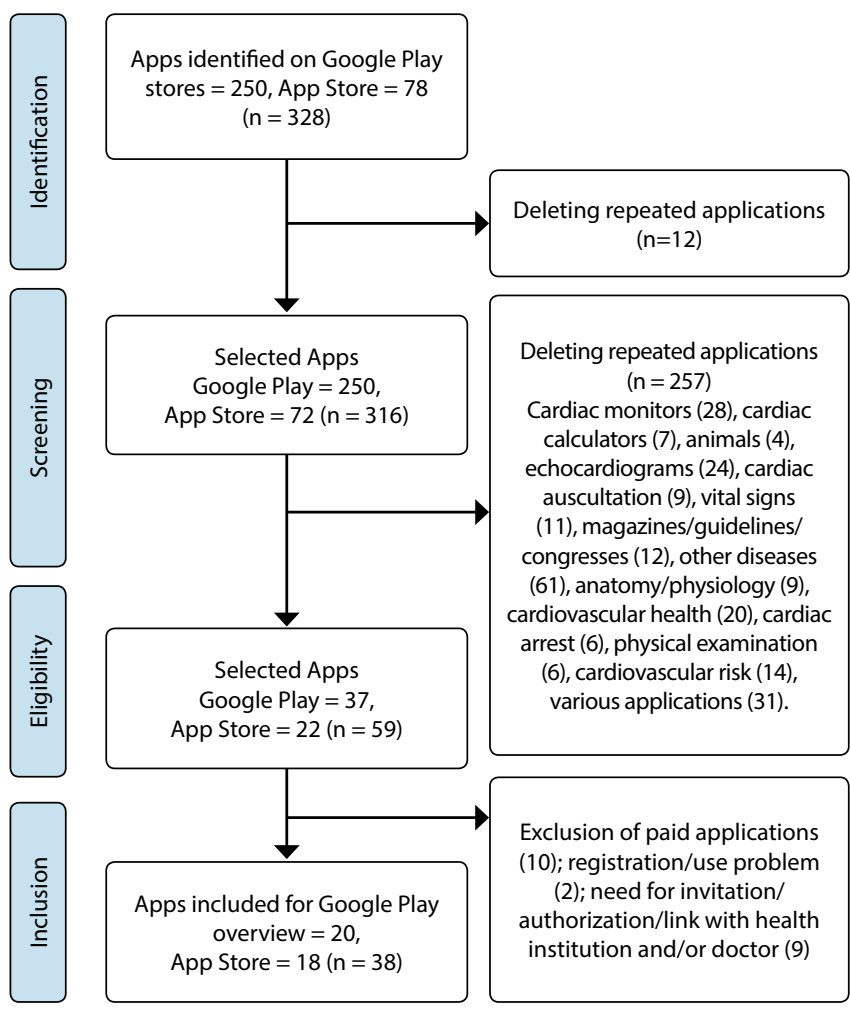

Figure 1 - Flowchart for selecting applications from selected virtual stores

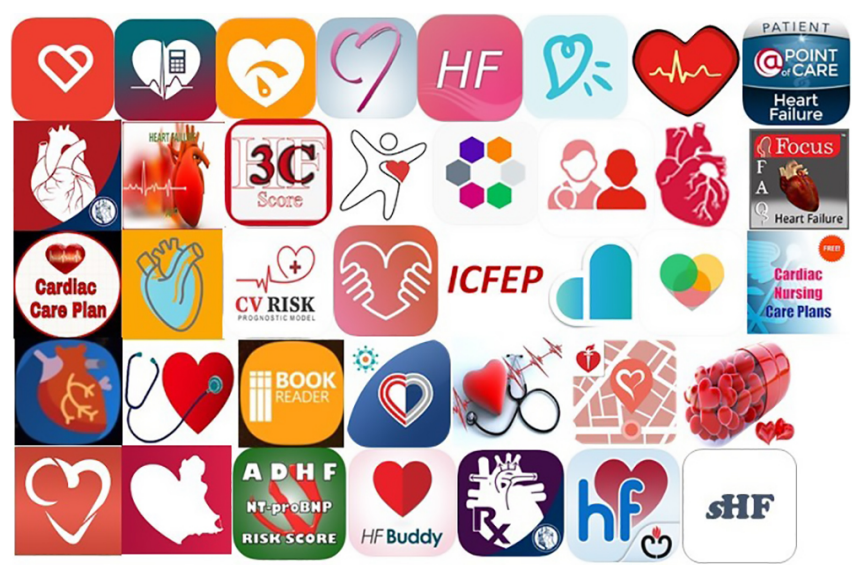

Figure 2 - Logos of the selected applications

The first APPs developed for patients with $\mathrm{HF}$ were launched in 2012 (2; 5.4\%). After 2013, there was a continuous increase, with a higher number launched in $2018(11 ; 28.9 \%)$ and, as of 2018, there was a reduction in launches. With regard to the country of origin, the United States concentrated the largest number of APPs, with 13 (34.3\%), followed by Spain (4; 10.6\%), Canada and Brazil (3; 7.9\%), Italy, United Kingdom and India (2; 5.3\% each), France, Germany, Singapore, Netherlands, Kuwait, Russia, Indonesia, Nigeria and Poland $(1 ; 2.6 \%$ each). Despite the variety of countries, English was the predominant language (28; 73.7\%), 
followed by Spanish (4; 10.6\%), Portuguese (3; 7.9\%), and French, German and Polish, with one (2.6\%) each.

The themes (descriptions/objectives) were diverse and included knowledge (educational), self-care (management, selfmanagement, monitoring and recognition of signs and symptoms and recording of physical activities), decision-making (choice of treatment and assistance guides), follow-up of patients (professional follow-up at the outpatient clinic and follow-up by the multidisciplinary team after hospital discharge), calculators for patients with HF (diagnosis, complications, prognosis and mortality/hospitalization) and Systematization of Nursing Care (care plans) (Table 1) .
APPs were targeted at health professionals, students and patients and their family members/caregivers. Among health professionals, two (5.3\%) were specific to primary care physicians and four (10.6\%) to nurses. Three (7.9\%) APPs were also directed to university students in the health field and only two (5.3\%) included family members/caregivers, although many patients with HF need their support to carry out their daily care.

The theme of knowledge was explored in 13 (34.2\%) APPs; the themes of self-care and decision-making were found in seven (18.4\%) each; six (15.8\%) APPs were developed to prepare calculations for patients with HF; three (7.9\%), for patient follow-up; two (5.3\%) brought the Systematization of Nursing Care.

Table 1 - Characterization of selected applications in Google Play (Android) and App Store (Apple) stores

\begin{tabular}{|c|c|c|c|c|c|c|}
\hline Application & Language & Description/Objective & Target audience & Version & $\begin{array}{l}\text { Stars / } \\
\text { ratings }\end{array}$ & Downloads \\
\hline MED-HF & English & $\begin{array}{l}\text { Support and guide health professionals on the use of } \\
\text { medications and recommend appropriate actions and } \\
\text { considerations for treatment; }\end{array}$ & Health professionals & 2.1 & $N I^{c}$ & $\mathrm{NI}$ \\
\hline iCerca & Spanish & $\begin{array}{l}\text { Help patients to recognize signs and symptoms and } \\
\text { manage their disease; }\end{array}$ & Patient & 1.1 & $\mathrm{NI}$ & $\mathrm{NI}$ \\
\hline HF Buddy & English & $\begin{array}{l}\text { Empower patients with knowledge for self- } \\
\text { management; }\end{array}$ & Patient & 1.1 & $1.0 / 2$ & $\mathrm{NI}$ \\
\hline $\begin{array}{l}\text { LifeCourse } \\
\text { Companion }\end{array}$ & English & Screen patients' daily aspects of their disease; & Patient & 1.0 .46 & $\mathrm{NI}$ & $\mathrm{NI}$ \\
\hline LifeCourse HF & English & Manage $\mathrm{HF}^{\mathrm{a}}$; & Patient & 1.1 & $\mathrm{NI}$ & $\mathrm{NI}$ \\
\hline $\begin{array}{l}\text { Medly for Heart } \\
\text { Failure }\end{array}$ & English & $\begin{array}{l}\text { Self-manage, with record of symptoms and real-time } \\
\text { feedback on health status; }\end{array}$ & $\begin{array}{l}\text { Health professionals and } \\
\text { patients }\end{array}$ & 1.4 .0 & $4.0 / 9$ & $\mathrm{NI}$ \\
\hline MyHeartAPP & English & $\begin{array}{l}\text { Screen and share with your healthcare professional the } \\
\text { HF status; }\end{array}$ & $\begin{array}{l}\text { Patient and health } \\
\text { professional }\end{array}$ & 1.14 & $3.6 / 7$ & $\mathrm{NI}$ \\
\hline WOW ME 2000mg & English & $\begin{array}{l}\text { Help patients learn and perform their daily self- } \\
\text { management tasks; }\end{array}$ & $\begin{array}{l}\text { Patient and family } \\
\text { member/caregiver }\end{array}$ & 1.1 & $4.0 / 3$ & $\mathrm{NI}$ \\
\hline $\begin{array}{l}\text { CV Risk Prognostic } \\
\text { Model }\end{array}$ & English & Assess mortality and hospitalization; & Health professionals & 1.1 & $5.0 / 7$ & $\mathrm{NI}$ \\
\hline $\begin{array}{l}\text { Patient Education } \\
\text { Atlases of Heart } \\
\text { Failure }\end{array}$ & English & $\begin{array}{l}\text { Help health professionals explain about HF in a clearer } \\
\text { and more objective way; }\end{array}$ & Health professionals & 1.0 & $\mathrm{NI}$ & $\mathrm{NI}$ \\
\hline Heart Failure Manager & English & $\begin{array}{l}\text { Allow patients to screen and store relevant health } \\
\text { information between visits to the doctor; }\end{array}$ & $\begin{array}{l}\text { Patient and health } \\
\text { professional }\end{array}$ & 10.5 .1 & $5.0 / 2$ & $\mathrm{NI}$ \\
\hline TreatHF & English & $\begin{array}{l}\text { Assist physicians in confirming which therapies are } \\
\text { suggested for their patients with reduced ejection } \\
\text { fraction and provides guidance on the use of each } \\
\text { therapy; }\end{array}$ & Health professionals & 1.1 .0 & $5.0 / 2$ & $\mathrm{NI}$ \\
\hline $\begin{array}{l}\text { Heart Failure } \\
\text { Storylines }\end{array}$ & English & $\begin{array}{l}\text { Allow the recording of symptoms, vital signs and } \\
\text { medications to help patients manage their disease; }\end{array}$ & Patient & 7.17 & $4.0 / 8$ & $>1,000$ \\
\hline HFPath & English & $\begin{array}{l}\text { Self-manage, teach how to control and manage } \\
\text { symptoms, weight and medication and educate patients } \\
\text { to take small steps to improve their quality of life; }\end{array}$ & Patient & 6.1 & $3.6 / 16$ & $>1,000$ \\
\hline HF Log & English & $\begin{array}{l}\text { Help patients screen their body weight and physical } \\
\text { activity; }\end{array}$ & $\begin{array}{l}\text { Health professionals and } \\
\text { patients }\end{array}$ & 1.0 & $5.0 / 2$ & $\mathrm{NI}$ \\
\hline $\begin{array}{l}\text { ADHF/NT-preBNP Risk } \\
\text { Score Calculator }\end{array}$ & English & $\begin{array}{l}\text { Predict 1-year mortality in patients hospitalized with } \\
\text { acute HF and left ventricular ejection fraction below } \\
30 \% \text {; }\end{array}$ & Health professionals & 1.0 & $\mathrm{NI}$ & $\mathrm{NI}$ \\
\hline $\begin{array}{l}\text { 3C-HF Score } \\
\text { Calculator }\end{array}$ & English & Stratify the risk of mortality of patients in one year; & Health professionals & 1.1 & $5.0 / 1$ & $\mathrm{NI}$ \\
\hline Systolic Heart Failure & English & Guide treatment according to functional classification; & Health professionals & 1.0 & $\mathrm{NI}$ & $\mathrm{NI}$ \\
\hline CardioCalc & French & Calculate diagnoses of complications of the disease; & Health professionals & 1.4 .1 & $4.0 / 1$ & $>1,000$ \\
\hline
\end{tabular}




\begin{tabular}{|c|c|c|c|c|c|c|}
\hline Application & Language & Description/Objective & Target audience & Version & $\begin{array}{c}\text { Stars / } \\
\text { ratings }\end{array}$ & Downloads \\
\hline $\begin{array}{l}\text { CardioSmart Heart } \\
\text { Explorer }\end{array}$ & English & Help patients understand their disease; & Patient & 2.3.0. & $4.5 / 213$ & $>50.000$ \\
\hline CardioVisual & English & $\begin{array}{l}\text { Provide explanations on risk factors, prevention, conditions } \\
\text { and treatments; }\end{array}$ & $\begin{array}{l}\text { Patient and health } \\
\text { professional }\end{array}$ & 5.1 .6 & $3.6 / 869$ & $>100,000$ \\
\hline Heart failure & English & Be an educational application; & Patient & 1.0 & $\mathrm{NI}$ & $\mathrm{NI}$ \\
\hline $\begin{array}{l}\text { Heart Failure-AZ } \\
\text { Discussions }\end{array}$ & English & Be an educational application; & $\begin{array}{l}\text { Health professionals, } \\
\text { students and patients }\end{array}$ & 1.0.6 & $\mathrm{NI}$ & $>1,000$ \\
\hline ICAPP & Spanish & $\begin{array}{l}\text { Provide simulation algorithms and treatments for care } \\
\text { processes; }\end{array}$ & Health professionals & 1.1.0. & $3.8 / 5$ & $>1,000$ \\
\hline ICFEP & Portuguese & Calculate the probability for ICFEP diagnosis ${ }^{b}$; & Health professionals & 1.0 & $\mathrm{NI}$ & $>50$ \\
\hline Insuficiencia cardíaca & Spanish & $\begin{array}{l}\text { Guide medical care in the diagnostic and therapeutic } \\
\text { process; }\end{array}$ & $\begin{array}{l}\text { Health professionals } \\
\text { (primary care) }\end{array}$ & 0.0 .1 & $4.9 / 5$ & $>5,000$ \\
\hline Clinical Cardiology & Portuguese & Be an educational application; & Health professionals & 1.0 & $4.4 / 31$ & $>5,000$ \\
\hline CardioExpert I & English & Calculate prognosis of the disease; & Health professionals & 7.6.235 & $4.9 / 1.129$ & $>100,000$ \\
\hline CarPriMur & Spanish & $\begin{array}{l}\text { Present flowcharts, recommendations and protocols for } \\
\text { primary care physicians; }\end{array}$ & $\begin{array}{l}\text { Health professionals } \\
\text { (primary care) }\end{array}$ & 1.4.4 & $5.0 / 10$ & $>100$ \\
\hline Heart failure & English & Improve patients' knowledge about their disease; & $\begin{array}{l}\text { Patients, health } \\
\text { professionals and } \\
\text { students }\end{array}$ & 3.0 & $\mathrm{NI}$ & $>10$ \\
\hline FAQs Heart Failure & English & $\begin{array}{l}\text { Provide answers to many questions of anatomy and } \\
\text { pumping function of the heart, HF causes, risk factors, } \\
\text { types and symptoms, diagnostic tests, medications, } \\
\text { implantable devices; }\end{array}$ & $\begin{array}{l}\text { Health professionals, } \\
\text { students, patients and } \\
\text { family/caregiver }\end{array}$ & 1.2 & $4.0 / 7$ & $>1,000$ \\
\hline Cardiac Care Plans & English & Planning nursing care; & Nurses & 1.2 & $\mathrm{NI}$ & $>100$ \\
\hline CardioMed & English & Guide on medicines; & Health professionals & 1.3.1 & $\mathrm{NI}$ & $>1,000$ \\
\hline $\begin{array}{l}\text { Cardiac Nursing Care } \\
\text { Plans }\end{array}$ & English & Create nursing care plans; & Nurses & 2.0 & $\mathrm{NI}$ & $>500$ \\
\hline Slabe Serce & Polish & Increase patient knowledge and awareness; & Nurses and patients & 1.0 .5 & $\mathrm{NI}$ & $<5$ \\
\hline $\begin{array}{l}\text { Leben mit } \\
\text { Herzinsuffizienz }\end{array}$ & German & Help patients cope daily with the disease; & Patients & 1.13 & $3.8 / 5$ & $>100$ \\
\hline $\begin{array}{l}\text { Rajan's HF (R-hf) Risk } \\
\text { Calculator }\end{array}$ & English & Estimate the risk of complications of patients; & Health professionals & 2.0 & $4.8 / 12$ & $>100$ \\
\hline CardioEnf-IC & Portuguese & $\begin{array}{l}\text { Monitor the post-discharge signs and symptoms of HF } \\
\text { patients by specialist nurses. }\end{array}$ & Nurses and patients & 1.03 & $\mathrm{NI}$ & $>10$ \\
\hline
\end{tabular}

$a=$ Heart failure; $b=$ Preserved Ejection Fraction Heart Failure; $c=$ Not informed; HF - Heart Failure; ICFEP - Heart Failure with Preserved Ejection Fraction; NI - not identified.

CardioVisual and CardioExpert I had more than 100,000 downloads and were the most evaluated. CardioVisual is aimed at healthcare professionals and patients and is in version 5.1.6; has 3.6 stars out of 869 reviews. CardioExpert I is version 7.6.235, with 4.9 stars out of 1,129 reviews. Other APPs with more advanced versions were Heart Failure Manager (v.10.5.1), Heart Failure Storylines (7.17) and HFPath (v.6.1).

Table 2 discusses information on the content, features, and usability of the selected APPs. The contents covered involved, mainly, habits (physical activity, weight control, feeding and water intake), well-being (living with the disease, mood and cognitive assessment), clinical data (anatomy, pathophysiology of the disease, vital signs and treatment) and disease management (management, postdischarge, multiprofessional follow-up and financial planning).

APPs contained various features: general, data insertion, diagnostics and those that require internet connection to control the management panel. Among the general ones, the use of texts (44.7\%), figures (21.1\%) and videos (18.4\%) was more common. In the data insertion features, users' profile data (15.8\%) and clinical data (55.3\%). As for the resources that required internet connection, the use of links $(4 ; 10.6 \%)$ and sending e-mails to health professionals $(4 ; 10.6 \%)$ were more observed.

In the usability analysis by SUS, it was observed that 34 APP (89.5\%) scored with a score $>68$ points, instrument cutoff score, and $16(42.1 \%)$ score above 85 . The agreement rate among the observers was $92.1 \%$, with $p>0.05$ for all items of SUS. Four (10.5\%) APP obtained a borderline score (between 50 and 67 points), but still acceptable. The APP that did not reach the cutoff point were Patient Education Atlas of Heart Failure (50 points), Heart Failure Manager (62.5 points), Systolic Heart Failure (62.5 points) and Clinical Cardiology (52.5 points). Scores below 50 are considered without usability.

Based on SURE, the agreement rate among the observers was $94.7 \%$, with $p>0.05$. It was found that four (10.5\%) APP were at level 30 (Patient Education Atlas of Heart Failure, Clinical Cardiology, Cardiac Care Plans and Cardiac Nursing Care Plans); two (5.3\%) at level 40 (Systolic Heart Failure and Heart Failure Info); seven (18.4\%) at level 50; eight (21.1\%) at level 70; $17(44,7 \%)$ at level 80. 
Table 2 - Characterization of selected applications for content, features and usability

\begin{tabular}{ll}
\hline Application & Content \\
\hline MED-HF & $\begin{array}{l}\text { Recommendations for initiation, titration, evaluation and } \\
\text { monitoring of medicines; }\end{array}$ \\
iCerca & $\begin{array}{l}\text { Symptoms, treatments, diagnoses, advice for the control of } \\
\text { signs and symptoms and to live with HF, what to do during } \\
\text { hospitalization and at discharge, advice to take care of health } \\
\text { at home, control vital signs, intake of liquids and weight, and } \\
\text { tips on how to prepare for consultation; }\end{array}$
\end{tabular}

HF Buddy Definition, causes, diagnosis, treatment, monitoring of symptoms, physical activities, diet and medication;

\section{Resources}

Texts, tables, algorithms and clinical issues;

Texts, figures, map, questionnaire of knowledge of the disease, sending the responses and result on the spot. Audio option (reading content), educational videos, signals the contents already viewed, enter user information (editable);

Text, videos, figures, audio option, allows recording $\mathrm{BP}, \mathrm{HR}$, weight, daily liquids, daily exercises and follow by graphics, record medications in use and symptoms (submit to see tips), alarm, provides APP usage guide;

LifeCourse Medication, quality of sleep, food and well-being;
Companion

LifeCourse HF

Medly for Heart Failure

MyHeartAPP

WOW ME 2000mg

CV Risk Prognostic Model

Patient Education

Atlases of Heart

Failure

Heart Failure Manager

TreatHF

Heart Failure Storylines

HF Path

HF Log signs of cardiac decompensation;

Physical activity, well-being and medications in use;

Symptoms, medications, well-being, functional class and weight;

Symptoms, blood pressure, heart rate, diet, weight, laboratory tests;

General information on HF and follow-up by health professionals (symptoms by date, weight, sodium, fluid intake);

Prognostic information in outpatients with chronic HF who receive the therapy recommended by the guideline;

Cardiac anatomy and physiology, ejection fraction (preserved and reduced), causes and consequences, signs and symptoms, classification, diagnosis and treatment;

Well-being, mood and quality of life, life habits, levels of difficulties to perform daily activities and cognitive assessment;

Evaluation parameters of HF (functional classification and ejection fraction) and medications;

Symptoms, vital signs, medications and well-being;

Weight and physical activity;
Video to learn how to handle the APP, record information about sleep, save files, medications in use, lifestyle (diet) - with graphics, diary, quiz (knowledge about the disease), library of medicines;

Registration and reminder of medications, weight, symptoms, daily well-being, $\mathrm{HF}$ classification;

Integration with the Health application to read and write your weight, blood pressure and heart rate readings, allows you to enter patient data and informs the doctor, real-time feedback about health, through alert messages generated, allows connection/phone call with the doctor/clinic, direct access to laboratory results, enter data of health professionals (multidisciplinary team);

Text, charts, stopwatch, daily steps, calendar, symptom list and activity list, enter daily weight, sodium and fluid intake. It makes it possible to filter and classify symptom information by date/symptom (identifies trends and patterns). Sending reports to health professionals by e-mail;

Recording weight, heart rate, sodium intake, water intake, number of daily steps, list of medications in use, symptoms, $\mathrm{BP}, \mathrm{HR}$, information of professionals who follow them, from the pharmacy, outpatient clinic and emergency, allows to make a phone call to these professionals;

Risk calculator and update of tests, register age, blood pressure, heart rate, ejection fraction, creatine, cholesterol, disease time, comorbidities, functional classification and use of ivabradine;

Record the consultation (image and sound), annotate, zoom in and out of the page, send by email (print and save drawings), useful texts for explanatory purposes, 3D illustrations;

Digital diary, insert photo, textual information and links, graphics, allows medical access, allows to compare how patients feel in relation to the previous day, manage medications and treatments, screen symptoms and specific side effects, option to print the graphics, allows to connect with the multidisciplinary team;

Text, enter general patient information, option to send e-mail;

Medication reminder, follow-up of symptoms and side effects and levels of physical activity, record vital signs, synchronize with other devices (import data from other health APP) and daily (report of well-being);

APP explanatory video, chat room, insert daily activities, weight, sleep, blood pressure, glucose and allows the visualization of these data in graphs; red), mark the day of the week, insert contact of the physical educator and allow notifications;
Usability

SUS ${ }^{\mathrm{a}}$ SURE $^{\mathrm{b}}$

$92.5 \quad 75$

$100 \quad 91$

$87.5 \quad 107$ 


\begin{tabular}{|c|c|c|c|c|}
\hline \multirow{2}{*}{ Application } & \multirow{2}{*}{ Content } & \multirow{2}{*}{ Resources } & \multicolumn{2}{|c|}{ Usability } \\
\hline & & & SUS ${ }^{a}$ & SURE \\
\hline $\begin{array}{l}\text { ADHF/NT-preBNP } \\
\text { Risk Score Calculator }\end{array}$ & $\begin{array}{l}\text { Calculation of mortality based on calculated glomerular } \\
\text { filtration rate, chronic obstructive pulmonary disease, } \\
\text { blood pressure, serum sodium, hemoglobin, type B } \\
\text { natriuretic peptide, tricuspid regurgitation, previous } \\
\text { hospitalization for HF; }\end{array}$ & $\begin{array}{l}\text { Reversal function for background/text colors, insert } \\
\text { parameters (scans) and calculation of immediate result; }\end{array}$ & 82.5 & 69 \\
\hline $\begin{array}{l}\text { 3C-HF Score } \\
\text { Calculator }\end{array}$ & Laboratory tests, comorbidities and therapy; & Enter test values, save results, and link to the study; & 82.5 & 77 \\
\hline Systolic Heart Failure & Classification and appropriate treatment; & Text and flowchart; & 62.5 & 40 \\
\hline CardioCalc & Laboratory and imaging tests and vital signs; & Menu with search bar, calculator with immediate response; & 87.5 & 85 \\
\hline $\begin{array}{l}\text { CardioSmart Heart } \\
\text { Explorer }\end{array}$ & Functioning of the heart with failure; & $\begin{array}{l}\text { Explanatory animations, 3D figures, videos and link for } \\
\text { sending comments; }\end{array}$ & 80.0 & 56 \\
\hline CardioVisual & $\begin{array}{l}\text { Cardiac function, HF types, management, monitoring, } \\
\text { functional class, treatment and ventricular assist devices; }\end{array}$ & $\begin{array}{l}\text { Explanatory video for use of the application and about } \\
\text { the disease, search option, records audios and chat with } \\
\text { professionals; }\end{array}$ & 80.0 & 70 \\
\hline Heart failure & $\begin{array}{l}\text { Definition, signs and symptoms, causes, pathophysiology, } \\
\text { diagnosis and classification, prevention and management, } \\
\text { prognosis, epidemiology, economics and research; }\end{array}$ & $\begin{array}{l}\text { Change background color and text, videos and connection } \\
\text { to Facebook; }\end{array}$ & 77.5 & 40 \\
\hline $\begin{array}{l}\text { Heart Failure-AZ } \\
\text { Discussions }\end{array}$ & $\begin{array}{l}\text { Etiology, signs and symptoms, complications and treatments } \\
\text { for patients with HF and acute pulmonary edema, refractory } \\
\text { HF and diastolic HF; }\end{array}$ & Text, pictures and e-mail to authors & 75.0 & 57 \\
\hline ICAPP & $\begin{array}{l}\text { Diagnosis, treatment and organization of care } \\
\text { (multidisciplinary programs: early post-discharge visit and } \\
\text { palliative care); }\end{array}$ & $\begin{array}{l}\text { Checking for signs and symptoms for clinical history and } \\
\text { physical examination. The options show an evolutionary } \\
\text { process: from the initial approach to treatment; }\end{array}$ & 85.0 & 62 \\
\hline ICFEP & $\begin{array}{l}\text { Probability score based on body mass index, age, medication } \\
\text { use, presence of atrial fibrillation and doppler result; }\end{array}$ & $\begin{array}{l}\text { Enter patient name and data, probability calculation and } \\
\text { immediate response; }\end{array}$ & 90.0 & 79 \\
\hline Insuficiencia cardíaca & $\begin{array}{l}\text { Definition, signs and symptoms, complementary tests, } \\
\text { causes, follow-up, treatment and differential diagnosis; }\end{array}$ & Text; & 82.5 & 79 \\
\hline Clinical Cardiology & $\begin{array}{l}\text { Definition, etiology, pathophysiology, compensation } \\
\text { mechanisms, signs and symptoms, clinical classification, } \\
\text { functional classification, complementary tests and treatment; }\end{array}$ & Link that directs to a PDF text; & 52.5 & 29 \\
\hline CardioExpert I & Prognosis, risk of mortality and six-minute walk test; & Enter age and clinical data, risk stratification for mortality; & 90.0 & 92 \\
\hline CarPriMur & $\begin{array}{l}\text { Follow-up of HF in primary care, hospital discharge and } \\
\text { therapeutic protocols; }\end{array}$ & $\begin{array}{l}\text { The options show an evolutionary process: initial approach, } \\
\text { symptoms presented and indicates whether to seek a health } \\
\text { institution. Cardiovascular risk calculators; }\end{array}$ & 87.5 & 80 \\
\hline Heart failure & $\begin{array}{l}\text { Definition, pathophysiology, etiology, epidemiology, } \\
\text { prognosis, clinical cases, differential diagnosis, diagnosis, } \\
\text { treatment, risk factors, complications and prevention; }\end{array}$ & Text, images and e-mail option for authors; & 77.5 & 61 \\
\hline FAQs Heart Failure & General knowledge about HF; & Text, images and videos; & 75.0 & 52 \\
\hline Cardiac Care Plans & $\begin{array}{l}\text { Nursing care plans (diagnoses, interventions and } \\
\text { justifications); }\end{array}$ & Text; & 70.0 & 32 \\
\hline CardioMed & $\begin{array}{l}\text { HF treatments: enalapril, digoxin, dopamine, } \\
\text { hydrochlorothiazide; }\end{array}$ & Search bar, text; & 75.0 & 51 \\
\hline $\begin{array}{l}\text { Cardiac Nursing Care } \\
\text { Plans }\end{array}$ & $\begin{array}{l}\text { Nursing care plans (diagnoses, interventions and } \\
\text { justifications); }\end{array}$ & Text, option to increase or decrease the font size; & 70.0 & 35 \\
\hline Slabe Serce & Lifestyle and symptoms; & Educational material with photos, quiz, printing option; & 87.5 & 82 \\
\hline $\begin{array}{l}\text { Leben mit } \\
\text { Herzinsuffizienz }\end{array}$ & Signs and symptoms, causes, classes of medications; & $\begin{array}{l}\text { Texts, video sequences, audio to written text and diary to } \\
\text { enter relevant information, option to increase/decrease letter } \\
\text { size, warnings that help to recognize the worsening of your } \\
\text { disease in a timely manner and react correctly; }\end{array}$ & 95.0 & 84 \\
\hline $\begin{array}{l}\text { Rajan's HF (R-hf) Risk } \\
\text { Calculator }\end{array}$ & Insert EF, eGFR, Hb and NT-proBNP; & Enter values and estimate calculation; & 85.0 & 75 \\
\hline CardioEnf-IC & $\begin{array}{l}\text { Information about the pathology and its clinical } \\
\text { manifestations and types of treatment. }\end{array}$ & $\begin{array}{l}\text { Enter general information, charts and reminders (medications } \\
\text { and consultations). }\end{array}$ & 90.0 & 102 \\
\hline
\end{tabular}




\section{DISCUSSION}

The growth of the Internet increases the sale of smartphones and, with this, studies of construction and validation of APP, which already exceeds $165,000^{(15)}$, portraying interest in the development of mobile technologies, collaborating in the construction of a new modality of health care ${ }^{(4)}$. This statement becomes clearer when observing the increasing construction of APP over the years.

Mobile APPs are shown to be innovative health care technologies. They are educational resources that allow improvement of teaching-learning, applied in different contexts ${ }^{(16)}$. In this sense, APPs, focusing on promoting patient knowledge, aims to meet the implementation of self-care practices ${ }^{(17)}$. In HF, self-care is vital to successful management. In an almost experimental research, HFApp, app for monitoring symptoms, reminders, education and screening of physiological data, proved effective to self-care, but was not significant in terms of awareness of the symptoms of the disease ${ }^{(6)}$.

The APP enables adequate follow-up of patients and assists in the clinical decision-making process of professionals, contributing to the development of reliable diagnoses and targeted therapeutic guidelines/conducts ${ }^{(3)}$, in addition to remote consultations ${ }^{(18)}$. In order to test the viability of a teleguidance APP with 692 german HF patients, a prospective study showed the technology as promising because it continuously reflected patient health information daily ${ }^{(19)}$. Thus, it allowed effective monitoring by health professionals, in addition to guiding decision-making.

With this technology, we can see the use by all those involved in the care process, in order to promote comprehensive care. When used by health professionals, it enables evidence-based practice. Therefore, it is relevant that professionals appropriate these tools to strengthen care and invest in safer care ${ }^{(17)}$. When developed for patients, APPs work as strategies that facilitate self-care, maintain autonomy and independence. For family members/caregivers, who play an important role in the care of HF patients, APPs are an additional form of information ${ }^{(5)}$.

Family members of patients with chronic diseases, such as $H F$, use the Internet to seek medical information more than the general public; on the other hand, use app ${ }^{(20)}$ less. One justification found by these authors is that, possibly, family caregivers do not have enough time or find it difficult to use mobile APP focused on care. Sociodemographic factors and poor health and digital literacy are also associated with limited access to and use of APP in health. However, when they use them, they become more informed and empowered ${ }^{(21)}$.

The development of an APP involves more than producing and delivering the product ready for the customer, requires a whole procedure that covers, including, the characterization of versions. Semantic versioning (SemVer) is a set of particularity rules that show how app version numbers were developed, that is, the amount of changes you have made and which changes were compatible or not with the previous version ${ }^{(22)}$. It is a set of good practices and customs of software development that indicates the larger version (major), minor version (minor) and patch version, arranged among ready: major.minot.patch.

SemVer is important to give the customer a notion of the software's stability status, enabling you to identify whether the new version has new features or bug fixes ${ }^{(23)}$. Thus, users can know what to expect when they will update the software ${ }^{(24)}$. In the APP analysed, increasing versions were observed, indicating adaptation of contents with terms and words used worldwide, such as the addition of functionalities. Thus, it is perceived that SemVer is a break from the way of being moved by keeping the APP up to date.

There was a number of varied downloads, a value calculated by the number of users who enter the APP page and download. However, this number does not mean number of mobile phones with the APP installed. Some factors can influence the count of downloads, such as competition between search engines. The best way to minimize this problem is to invest in both stores to host the APP. In addition, having both versions is recommended for good performance, in addition to the reach of a larger number of people without restriction of use on only one of the operating systems.

In addition, APPs presented a variety of functions, essential for disease management. Although HF has no cure, changes in lifestyle can increase patients' quality and life expectancy. Continuous monitoring and care of daily vital signs allows to recognize changes or complications early. However, self-monitoring rates are low, as patients often forget to record relevant information, such as signs and symptoms, vital signs, and medications in use ${ }^{(4)}$. This complicates check-ups and makes it difficult to identify your condition's worsening.

Thus, APP that provide resources that offer a comfortable use for patients, with interactive elements that provide reliable information, such as data insertion, can increase patient safety, decrease hospitalization episodes, and share their data with health professionals. APP with risk stratification and diagnostics are essential tools for health professionals and patients for providing prognosis and personalized treatment ${ }^{(25)}$.

When designing an interactive system, it is necessary to seek an understanding of users' needs, so that one can meet, with objectivity and quality, the desired experience in performing the task that will be projected ${ }^{(26)}$. The criterion regarding the material relevance and its applicability is important if it presents a valid and understandable content for a target audience, but does not have viable and relevant applicability, this material needs to be critically rethought ${ }^{(27)}$.

Usability is a prerequisite for spreading mobile APP use to health and is defined as a set of software attributes that are based on the effort required for the use and individual evaluation of such use by an implicit set of users. The usability score is intrinsically correlates with better reliability of ${ }^{(28)}$ content. Added to these factors are the lack of confidence in technology, frustration with design and navigation features, and an interest in having technology to support your self-management of the ${ }^{(29-30)}$ disease.

The use of mobile APP usability questionnaires is important because of special components such as connectivity issues, battery and security and privacy challenges ${ }^{(31)}$. There are several ways to conduct a usability study, being the use of questionnaires, the fastest and most practical way. The usability of the APPs analyzed was evaluated by two independent researchers using two instruments: SUS, which evaluates the general context $^{(11)}$ and SURE, smartphone-specific ${ }^{(13)}$. According to the SUS 
instrument, the vast majority of APPs scored above the cut-off score of the instrument.

Although SUS is widely used, this instrument was not designed to evaluate the usability of mobile health APP ${ }^{(31)}$. Thus, it was also decided to use SURE. It was found that the majority were at level 80 of sure, level at which respondents begin to fully agree that the help /tip given by the APP was useful, in addition to anure with the other items. This demonstrates the high level of satisfaction, which establishes intelligibility, learning, operability, attractiveness, and compliance with the ${ }^{(32)}$ usability goals.

The repercussion of APPs for HF is vast and relevant, as it includes important themes, directed to all those involved in the care process. Therefore, it is necessary to support development and improvement, with a view to improving health practices. However, it was observed that themes such as vulnerability in health, mental health, sexual activity, social and family support, palliative care, side effects of medications, vaccinations and family planning were not addressed.

It was observed that, among health professionals, only physicians and nurses were contemplated. Multidisciplinary team support plays a crucial role to improve the quality of life of patients and family members since the diagnosis of the disease ${ }^{(33)}$, being the gold standard for monitoring patients with HF and its multiple comorbidities. This includes physicians, nurses, psychologists, nutritionists, pharmacists, dentists, physiotherapists, physical educators and social workers ${ }^{(34)}$. Furthermore, it is important to highlight the absence of a caregiver as a user.

\section{Study limitations}

It is worth noting that the research presented limitations regarding searches, such as the non-inclusion of paid APP and/ or that required registration by the institution or health professional, making it impossible to handle.

\section{Contributions to nursing and health}

Furthermore, the results strengthen the current knowledge about the APP available for download and handling about HF, by exploring the thematic scope and usability. Furthermore, it makes possible the identification of gaps, aiming at the development of new APPs that address relevant and indispensable themes, together with the appropriate usability. Moreover, it directs the use of resources that assist professionals, patients and family/caregivers in the involvement and adhering of care and in clinical decision-making.

\section{FINAL CONSIDERATIONS}

The APPs currently available on HF have comprehensive content and adequate usability that can guide patients, family members/ caregivers, health students, physicians and nurses. However, the findings showed the need to develop PAAs with more themes, such as vulnerability in health, palliative care, mental health, social support, sexual activity, essential in the care of patients with $\mathrm{HF}$, in addition to the integration of other professionals from the multidisciplinary team.

\section{REFERENCES}

1. Lippi G, Sanchis-Gomar F. Global epidemiology and future trends of heart failure. AME Med J. 2020;5(15):1-6. https://doi.org/10.21037/ amj.2020.03.03

2. Mayer MA, Blanco OR, Torrejon A. Use of health APP by nurses for professional purposes: web-based survey study. JMIR Mhealth Uhealth. 2019;7(11):e15195. https://doi.org/10.2196/15195

3. Barra SCC, Paim SMS, Sasso GTMD, Colla GW. Métodos para desenvolvimento de aplicativos móveis em saúde: revisão integrativa da literatura. Texto Contexto Enferm. 2017;26(4):1-12. https://doi.org/10.1590/0104-07072017002260017

4. Arulnathan A, Vaaheesan S, Denecke K. A mobile APPlication for self-monitoring for patients with heart failure. Stud Health Technol Inform. 2019;259:113-6. https://doi.org/10.3233/978-1-61499-961-4-113

5. Amorim DNP, Sampaio LVP, Carvalho GA, Vilação KHC. Mobile APPlications for the health and care of elderly. Rev Eletron Comun Inf Inov Saúde. 2018;12(1):58-71. https://doi.org/10.29397/reciis.v12i1.1365

6. Foster M. A mobile APPlication for patients with heart failure: theory- and evidence-based design and testing. Comput Inform Nurs. 2018;36(11):540-9. https://doi.org/10.1097/CIN.0000000000000465

7. Martinez-MillanaA, Jarones E, Fernandez-Llatas C, Hartvigsen G, Traver V. APP features for type 1 diabetes support and patient empowerment: systematic literature review and benchmark comparison. JMIR Mhealth Uhealth. 2018;6(11):e12237. https://doi. org/10.2196/12237

8. Athilingam P, Jenkins B. Mobile phone APP to support heart failure self-care management: integrative review. JMIR Cardio. 2018;2(1):1-16. https://doi.org/10.2196/10057

9. Wali S, Demers C, Shah H, Wali H, Lim D, Naik N, et al. Evaluation of heart failure APP to promote self-care: systematic APP search. JMIR Mhealth Uhealth. 2019;7(11):e13173. https://doi.org/10.2196/13173

10. Cestari VRF, Moreira TMM, Pessoa VMP, Florêncio RS. Insuficiência cardíaca: interface com a vulnerabilidade em saúde. Curitiba: Editora CRV; 2019.

11. Tenório JM. Desenvolvimento e avaliação de um protocolo eletrônico para atendimento e monitoramento do paciente com doença celíaca. Rev Inform Teor Apl. 2010;17(2):210-20. https://doi.org/10.22456/2175-2745.12119

12. Lima CJM, Coelho RA, Medeiros MS, Kubrusly M, Marçal E, Peixoto Júnior AA. Desenvolvimento e validação de um aplicativo móvel para o ensino de eletrocardiograma. Rev Bras Educ Med. 2019;43(1):166-74. https://doi.org/10.1590/1981-5271v43suplemento1-20190164 
13. Wangenheim CG, Borgatto AF, Nunes JV, Lacerda TC, Oliveira RJ, Krone C, et al. Sure: uma proposta de questionário e escala para avaliar a usabilidade de aplicações para smartphones pós-teste de usabilidade [Internet]. In: Interaction South America: 6a Conferencia Lationamericana de Diseño de Interacción; 2014 nov 19-22; Buenos Aires: Universidad Católica Argentina; 2014 [cited 2020 Aug 12], p. 1-8. Available from: https://repositorio.uca.edu.ar/bitstream/123456789/7958/1/sure-proposta-questionario-escala.pdf

14. Alexandre NMC, Clouci MZO. Validade de conteúdo nos processos de construção e adaptação de instrumentos de medidas. Ciênc Saúde Coletiva. 2011;16(7):3061-8. https://doi.org/10.1590/S1413-81232011000800006 2011

15. Gomes MLS, Rodrigues IR, Moura NS, Bezerra KC, Lopes BB, Teixeira JJD, et al. Evaluation of mobile APP for health promotion of pregnant women with preeclampsia. Acta Paul Enferm. 2019;32(3):275-81. https://doi.org/10.1590/1982-0194201900038

16. Silveira MS, Cogo ALP. Contribuições das tecnologias educacionais digitais no ensino de habilidades de enfermagem: revisão integrativa. Rev Gaúcha Enferm. 2017;38(2):e55204. https://doi.org/10.1590/1983-1447.2017.02.66204

17. Mendez CB, Salum NC, Junkes C, Amante LN, Mendez CML. Aplicativo móvel educativo e de follow up para pacientes com doença arterial periférica. Rev Latino-Am Enfermagem. 2019;27:e3122. https://doi.org/10.1590/1518-8345.2693-3122

18. Müthing J, Brüngel R, Friedrich CM. Server-focused security assessment of mobile health APP for popular mobile platforms. J Med Internet Res. 2019;21(1):e9818. https://doi.org/10.2196/jmir.9818

19. Werhahn SM, Dathe H, Rottmann T, Franke T, Vahdat D, Hanseful G. Designing meaningful outcome parameters using mobile technology: a new mobile APPlication for telemonitoring of patients with heart failure. ESC Heart Failure. 2019;6(3):516-25. https://doi.org/10.1002/ ehf 2.12425

20. Kim H, Powell MP, Bhuyan SS. Seeking medical information using mobile APP and the internet: are family caregivers different from general public? Med Syst. 2017;41(3):38. https://doi.org/10.1007/s10916-017-0684-9

21. Conceição LSE, Pessôa LAGP. Low literate consumers: experience in social media and instant messengers: an exploratory research. Soc Cont Gestão. 2018;13(3):1-19. https://doi.org/10.21446/scg_ufrj.v13i3.13521

22. Pressman RS, Maxim BR. Engenharia de software: uma abordagem profissional. 6 ed. São Paulo: McGraw-Hill; 2016.

23. Fernandes JM, Machado RJ. Requisitos em projetos de software e de sistemas de informação. São Paulo: Novatec; 2017.

24. Marinacci J. Construindo aplicativos móveis com JAVA. São Paulo: Novatec; 2012.

25. Bayés-Genís A, Lupón J. The Barcelona Bio-HF Calculator. JACC: Heart Failure. 2018;6(9):807-11. https://doi.org/10.1016/j.jchf.2018.06.001

26. Lowdermilk T. Design centrado no usuário: um guia para o desenvolvimento de aplicativos amigáveis. São Paulo: Novatec; 2019.

27. Girão ALA, Sampaio RL, Aires SF, Oliveira ICL, Oliveira SKP, Carvalho R. MEDSAFE: protótipo de um jogo virtual sobre preparo e administração de medicamentos. Rev Min Enferm. 2019;23:e1239. https://doi.org/10.5935/1415-2762.20190087

28. Yasinia M, Marchand G. Mobile health applications, in the absence of an authentic regulation, does the usability score correlate with a better medical reliability?. Stud Health Technol Inform. 2015;216:127-31. https://doi.org/10.3233/978-1-61499-564-7-127

29. Sarkar U, Gourley Gl, Lyles CR, Tieu L, Clarity C, Newmark L, et al. Usability of commercially available mobile applications for diverse patients. J Gen Intern Med. 2016;31(12):1417-26. https://doi.org/10.1007/s11606-016-3771-6

30. Sousa CS, Turrini RNT. Desenvolvimento de aplicativo de celular educativo para pacientes submetidos à cirurgia ortognática. Rev Latino-Am Enfermagem. 2019;27:e3143. https://doi.org/10.1590/1518-8345.2904.3143

31. Zhou L, Bao Jie, Setiawan MA, Dantono A, Parmanto B. The mHealth APP Usability Questionnaire (MAUQ): development and validation study. JMIR mHealth uHealth. 2019;7(4):e11500. https://doi.org/10.2196/11500

32. Guimarães C, Santos F, Fontana IM. Design e engenharia de usabilidade: aplicação prática na criação de um aplicativo. Design Technol. 2017;14:11-29. https://doi.org/10.23972/det2017iss14pp11-29

33. Kida K, Doi S, Suzuki N. Palliative care in patients with advanced heart failure. Heart Failure Clin. 2020;16(2):243-54. https://doi.org/10.1016/j. hfc.2019.12.006

34. Comitê Coordenador da Diretriz de Insuficiência Cardíaca. Diretriz Brasileira de Insuficiência Cardíaca Crônica e Aguda. Arq Bras Cardiol [Internet]. 2018 [cited 2020 Aug 18];111(3):436-539. Available from: http://publicacoes.cardiol.br/portalf/abc/portugues/2018/v11103/ pdf/11103021 